\title{
A vila de Melide entre fins do século XV e principios do século XVI
}

\section{Cristina Vázquez Neira Xurxo Broz Rodríguez}

Museo da Terra de Melide 


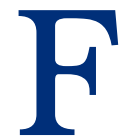
acer unha configuración urbanística e social da vila de Melide a finais da Idade Media e inicios da Moderna e intentar describir a paisaxe urbana que acolleu os participantes na asemblea de nobres e prelados do 4 de decembro de 1520 comporta un proceso de recollida de documentación extenso e laborioso.

Moitas son as fontes que se refiren ás distintas casas e inmobles existentes na vila (actas de compravenda, aforamentos, escrituras...) pero poucas as que describen con exactitude o seu trazado ou a propia estrutura urbana, o que nos obriga a compoñer un crebacabezas a través do perfil actual do Melide vello, ademais de poder delimitar a súa ordenación a través dos testemuños escritos. As numerosas fontes documentais nas que podemos basear o noso estudo para definir o trazado urbanístico que tería a vila a finais da Idade Media inclúen o Libro Becerro do Convento de Sancti Spiritus e o Tombo de Sobrado, nos que podemos obter unha exhaustiva listaxe de bens e inmobles propiedade de ambas as institucións claustrais, así como os foros que posuían. Contamos, ademais, coas actas do Preito Tavera-Fonseca, nas que podemos ler unha precisa descrición do castelo da mitra, que en 1520 xa estaba practicamente desmantelado por completo. A través destes documentos podemos extraer tamén datos dos distintos oficios e casas gremiais existentes a comezos da Idade Moderna e da súa organización, dos cales conservamos o Libro da Confraría de Santa Catarina de curtidores e zapateiros, que nos ofrece información detallada dende o século XVII ata o XIX.

Cabe mencionar que esta vila, na que tivo lugar tan importante acontecemento histórico, foi amplamente estudada en profundidade tanto por eruditos locais que a finais do século XIX e principios do XX sentiron a necesidade de afondar máis no pasado prolífico en episodios transcendentais para a historia do país ${ }^{1}$, como por historiadores contemporáneos que fixeron un amplo estudo sobre a Revolta Irmandiña, o paso de Carlos I e, por suposto, a asemblea de 1520. Autores como Eduardo Álvarez Carballido e Antonio Taboada Roca ${ }^{2}$ (ambos correspondentes da Real Academia Galega) iniciaron un labor continuado ata tempos presentes por investigadores locais (A. Hermida Rodríguez, M. Mejuto Sesto ou X. M. Broz Rei) e foráneos de estudo, recollida e publicación da docu-

1. En 1467 reuníronse en Melide os líderes irmandiños na súa primeira xuntanza e en 1520 tivo lugar a asemblea de nobres e prelados.

2. E. Álvarez (1843-1913) foi médico de profesión e publicou numerosos traballos en Galicia Histórica e Galicia Diplomática. A. Taboada Roca (1889-1978), farmacéutico, foi membro do Seminario de Estudos Galegos e participou no Terra de Melide elaborando o capítulo de historia e xenealoxía. 
mentación existente sobre o pasado medieval e moderno de Melide, que serven para situar esta vila non só na cerna xeográfica de Galicia, senón tamén como lugar onde sucederon grandes e importantes feitos que dirimiron a historia durante eses séculos.

Pero, do mesmo xeito, resulta anecdótico que tales sucesos non producisen unha pegada na memoria colectiva e histórica dos habitantes, xa que eses tres grandes acontecementos non deixaron constancia nin en rúas, nin en inmobles nin en historias locais de contos e lendas referidas a estes feitos. Resulta cando menos peculiar que no ano 1520 , en pouco menos de nove meses, tivesen lugar dous acontecementos importantes: a visita do rei Carlos I e o desenvolvemento da asemblea, que posiblemente trastornasen a vida cotiá nesas xornadas. Porén, deles non quedou testemuño ningún nos libros do convento de Sancti Spiritus, nos que non aparece ningunha mención ao paso do rei-emperador 234 nin tampouco da xuntanza que reuniu a máis alta nobreza laica e eclesiástica de Galicia, como si ocorre noutros documentos da época alleos a Melide, nos que aparecen reflectidos estes feitos.

Polo tanto, a través das fontes documentais existentes e dos traballos levados a cabo na segunda metade do século xx, podemos facer unha aproximación bastante precisa de como era a vila de Melide o 4 de decembro de 1520 e do escenario que atoparon os asistentes á dita reunión. A través dela trazaremos a súa delimitación urbana así como a súa orixe e os acontecementos que levaron a configurar o espazo que acolleu os asistentes, cun castelo propiedade da mitra xa derrocado e cunha cerca perimetral da vila que tempo despois foi obxecto igualmente de desmantelamento. Para a dita descrición cómpre iniciar o tema co nacemento do Burgo Novo de Melide, a quen pertencía a posesión do seu señorío e os factores que influíron no seu desenvolvemento. 


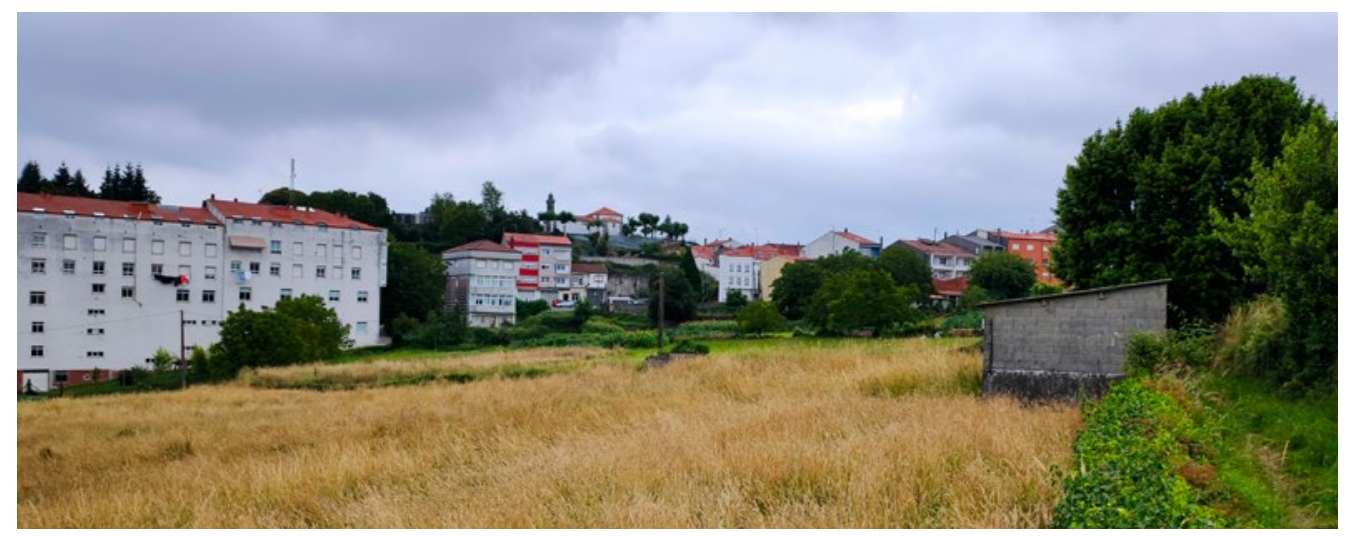

Fig. 1: Os Tagarros, núcleo orixinal do asentamento do Melide altomedieval. Ao fondo vese o outeiro do castro, onde se asentou no século XIV a fortaleza da mitra. $\mathrm{Na}$ actualidade podemos ver a capela do Carme.

\section{- Incorporación á mitra compostelá}

O Señorío das Terras de Abeancos, entre as que se atopaba o Burgo de Melide pertencente á Coroa, foi cedido mediante unha escritura asinada o día 9 de setembro do ano 1212 polo rei Afonso IX á Igrexa de Santiago, data en que ocupaba a mitra o arcebispo Pedro Muñiz. Este territorio pasaba así a incorporarse á xurisdición de Santiago, que rexería política e administrativamente este territorio dende ese momento. No entanto, o dereito eclesiástico e o poder sobre a Igrexa estaban nas mans da diocese de Mondoñedo, a quen pertencía o arciprestado de Abeancos e Melide, que ademais cobraba rendas. A partir de entón, a Terra de Abeancos e o Burgo de Melide serían propiedade da mitra compostelá, que os administraría baixo o réxime de tenencia. Precisamente nese ano de 1212 era prestamero ou tenenciero o nobre castelán Álvaro Núñez de Lara, casado con dona Teresa de Traba, sobriña de Pedro Froilaz. A vila de Melide,

3. A excepción do coto do Leboreiro, que quedaba en mans reais, así como o coto do Meire, que fora doado polo rei García de Galicia ao mosteiro de Santo Antoniño de Toques en 1067. As rendas e impostos pertencentes ao fisco real que se recadaban na vila de Melide foron doados polo rei Fernando II á enfermaría do mosteiro de Sobrado dos Monxes por un privilexio do ano 1185, polo que non é posible saber en que momento e en virtude de que título pasou á mitra un terzo das rendas de Melide (Hermida Rodríguez 1985b). 
non obstante, sería rexida por alcaldes en determinados momentos, como en 1257, cando o eran Domingo Martín e Domingo Iohanis ${ }^{4}$.

Pero, cando no ano 1252 sobe ao trono de Castela Afonso X, as cousas mudan pola política anexionista do monarca, quen pretendía reunir para a Coroa toda a autoridade posible. Nese momento promulga e asina ordenanzas para a Terra de Santiago, entre as que se inclúen Abeancos e o Burgo de Melide. Entre os anos 1266, co pasamento do arcebispo Juan Arias, e o ano 1273, co nomeamento de Gonzalo Gómez ${ }^{5}$, a sé compostelá estivo vacante, con episodios de carácter anárquico que provocaron altercados nas terras do feudo arcebispal. Foi entón nese ano de 1273 cando o rei Afonso X decide enviar o seu fillo, o infante Don Sancho (futuro rei Sancho IV), a Compostela para lle retirar todos os privilexios ao recentemente nomeado arcebispo Gonzalo Gómez e despoxalo da posesión do señorío para incorporalo de novo á Coroa. A partir daquela, Santiago e as súas terras xurisdicionais, entre as que se inclúen Abeancos e o Burgo de Melide, convértense en propiedade real e pasan a ser administradas civilmente por Juan Rodríguez e eclesiasticamente polo abade de Valladolid, Pelayo Pérez. Non dura moito este cambio de xurisdición xa que no ano 1284 ascende ao trono de Castela Sancho IV, despois da sublevación levantada contra o seu pai, Afonso X. Como unha das súas primeiras medidas, declara a devolución do señorío das terras de Santiago á mitra compostelá e inclúe, polo tanto, a Terra de Abeancos e o Burgo de Melide, que de novo pasan a ser propiedade da mitra ${ }^{6}$.

Durante o período en que é arcebispo Rodrigo de Padrón, entre 1307 e 1316, ten lugar a edificación da torre da homenaxe no alto do castro, no lugar que ata o momento posiblemente ocupaba unha pequena edificación propiedade da mitra, dende a que exercían o señorío ${ }^{7}$. Rodrigo de Padrón concede a tenencia do Burgo de Melide a Fernán Fernández de Aveancos e á súa dona Teresa Sánchez por unha renda de mil marabedís coa condición de construír unha torre da homenaxe de tres sobrados, así como de cercala de «muro bo», tanto a vila como o castelo. Pero sabemos que a vila foi cercada algúns anos despois, no ano 1320, mediante o Dereito de Castelaxe, asinado o 15 de xullo e concedido por Afonso XI ao arcebispo dese momento, Berenguel de Landoira, no que se lle autorizaba a cobrar «la castillaje de todas las bestias que por y passasen e todas las otras cosas

\footnotetext{
4. Hermida Rodríguez 1984.

5. Mentres tanto, tivo lugar o breve arcebispado de Egas Fafes entre 1268-1269 (Hermida Rodríguez 1984).

6. Hermida Rodríguez 1984.

7. Mejuto Sesto 2006.
} 
segunt que las toman en Triacastela y en Sarria». Este dereito tiña en principio unha duración de seis anos, coa finalidade de rematar a cerca da vila ${ }^{\mathbf{8}}$.

No ano 1317 é nomeado como novo arcebispo o francés Berenguel de Landoira polo papa de Avignon Xoán XXII. Cómpre dicir que, antes de tomar posesión na sé arcebispal ${ }^{9}$, fixo uso dun dereito que viña de antigo e que certificaba a importancia do dominio sobre o Burgo de Melide e o papel que a fortaleza aquí levantada exercía sobre as terras de Santiago:

Desde muy antiguo y que se sepa hasta el siglo XviII, aquí acudían los prohombres y vasallos de la Mitra Compostelana a rendir pleitohomenaje a los nuevos arzobispos. Durante los varios días que Don Berenguel permaneció en el pueblo acudieron a cumplimentarle el Infante don Felipe, tío del rey y Pertiguero de Santiago desde el año 1310 y don Alfonso de Suárez de Deza, Adelantado Mayor de Galicia desde el año $1311^{10}$.

A finais do século xv o conde de Monterrei, Sancho Sánchez de Ulloa, fíxose co señorío da vila de Melide e das súas terras e quitoulle a propiedade e rendas ao arcebispo de Santiago. Unha das accións que levou a cabo foi a utilización das pedras do derrocado castelo da mitra durante a Segunda Revolta Irmandiña, e con elas reedificou dous edificios no burgo de Melide: o convento que os frades regulares da Terceira Orde de San Francisco posuían extra muros da vila, así como o hospital para a atención de peregrinos e pobres que eles mesmos rexentaban fronte ao convento. Entre estes dous inmobles pasaba o Camiño Primitivo de Santiago.

Non foi ata o ano 1530 cando o rei Carlos I concedeu de novo o dereito señorial sobre as Terras de Abeancos e o Burgo de Melide ao arcebispo de Santiago, Juan Pardo de Tavera, polo que, durante o transcurso da Asemblea de Melide, o 4 de decembro de 1520, a vila de Melide estaba baixo dominio xurisdicional do conde de Monterrei, casualmente un dos ausentes na reunión ${ }^{\mathbf{1 1}}$.

8. Mejuto Sesto 2006. Tombo B da Catedral de Santiago, fol. 24.

9. Antes de poder tomar posesión da nova sé, foi rexeitado en varias ocasións pola cidade ata que finalmente, froito da súa habilidade diplomática, conseguiu entrar.

10. Hermida Rodríguez 1985a.

11. Nese momento o Condado de Monterrei estaba en mans de Francisca de Zúñiga, filla de Sancho de Ulloa e de Teresa Zúñiga, da casa de Monterrei. Francisca estaba casada en segundas nupcias co conde de Andrade, que si asistiu á asemblea no seu nome e no da súa muller. 


\section{- O castelo de Melide}

Pouco se sabe da edificación e aspecto do castelo que a mitra compostelá posuía na vila de Melide. As descricións existentes proveñen todas do Preito Tavera-Fonseca e fan referencia ás declaracións que achegan as testemuñas interrogadas con relación ás posesións da mitra. A través deste documento sabemos que sufriu danos importantes durante o levantamento irmandiño, que lle causaron graves estragos tanto na torre da homenaxe como nas defensas, e que posteriormente, a finais do século $\mathrm{xV}$, foron empregadas as súas pedras na reedificación de diversos inmobles de Melide, como o convento de Sancti Spiritus e o hospital do mesmo nome. Pero que nos conta esta fonte e que datos podemos extraer dela para coñecer como era esta fortaleza e a importancia que tiña?

A inicios do século XIV, o arcebispo Rodrigo de Padrón ordena levantar «una torre de tres sobrados» no alto do outeiro do castro ${ }^{12}$. Existen datos desa fortaleza durante o século XIV e inicios do XV a través da mención indirecta a ela en diferentes documentos, como o dereito de pasar a noite dos arcebispos unha vez nomeados, que exerceu Berenguel de Landoira no ano 1317, ou a sinatura en agosto de 1402 do Testamento de Gonzalo Ozores de Ulloa, señor do castelo de Pambre, en favor do seu primoxénito, Lope Sánchez de Ulloa, aínda menor de idade, e que foi asinado no castelo de Melide.

Non volvemos ter datos do castelo ata as declaracións das testemuñas do Preito Tavera-Fonseca, onde se narran os acontecementos ocorridos durante a Revolta Irmandiña e o que sucedeu co castelo. Este acto de conciliación entre o arcebispo entrante, Juan Pardo de Tavera, e o saínte, Alonso III de Fonseca e Ulloa, tivo lugar a partir do ano 1525 (cinco anos antes, cando tivo lugar a asemblea, Fonseca aínda era arcebispo de Santiago). As actas do preito, ademais da descrición das posesións da mitra en todas as súas terras, refírennos datos interesantes da configuración do castelo de Melide e da súa importancia como principal fortaleza da mitra en todos os seus dominios. Os declarantes interrogados foran testemuñas visuais dos acontecementos sucedidos cincuenta e oito anos antes durante o levantamento irmandiño. Cómpre indicar que a maioría deles serían rapaces, pero evidencian nas súas declaracións o coñecemento que posuían sobre esta fortaleza, a súa configuración e as causas da súa destrución. Así, na pregunta XIX do preito, referida en exclusividade á fortaleza de Melide, o que nos reporta a xa mencionada importancia que tiña sobre o resto de posesións, pregúntaselles: 
que digan e declaren que torres y edificios había y quien los derribó, y en tiempo de que Arzobispo, y por que causa, e si saben que la dicha fortaleza era la más importante y más necesaria de cuantas tenía y tiene el estado de Santiago, anssí por ser la llave y entrada del Arzobispo, como por los muchos y grandes adversarios que tiene alrededor en aquella comarca.

Ante esta pregunta queda constancia de que o castelo de Melide era a casa principal e máis forte da mitra, posto que así o deixan explícito. Do mesmo xeito, continúa preguntando

e si saben que el dicho Señor Patriarca dio la piedra de la dicha Fortaleza, al Conde Don Sancho, para azer el Monaterio de Sancti Spiritus de la dicha villa de Mellid.

A raíz disto xa nos metemos na outra cuestión importante referida ao castelo, a da súa completa destrución e a reutilización das súas pedras, o que comportou a desaparición total deste. As respostas, todas moi similares, transcríbennos a descrición do castelo e demais cuestións formuladas polos interrogadores. Así, Gonzalo de Sobrado, veciño de San Cosme de Abeancos, responde:

que la vido estar levantada e alta, e que vido tenía una vara de casa alta, que tenía cuatro o cinco sobrados [...] e que era de piedra menuda e las ventanas e puertas e esquinas della, de piedra de grano, e que alrededor de dicha vara de casa, había unas casas e palacios de morada, terrenas, donde vivían e se acogían e que el sitio estaba todo cercado con una barbacana de abaxo en la puerta por donde entraban, e que alderredor de la dicha cerca, había algunas casas terreñas, e la dicha vara de casa, era cubierta o tejada con teja.

Grazas a estas declaracións coñécese a descrición do castelo e o artellamento das súas defensas, constituídas por unha cerca e unha barbacá que a rodearía por completo. Tamén refiren que, durante a Segunda Revolta Irmandiña, os enfrontamentos derrocaron parte da torre da homenaxe nunha das súas esquinas:

e quedaban tres esquinas enteras y también derrocara el peitoril de los muros, e cerca de la dicha villa e las casas, que estaban anssí dentro de la dicha fortaleza, como las de alrrededor que dicho tiene e dice el dicho testigo, que no es acordado en que tiempo de que arzobispo fue dicho derrocamiento. 
Mais cita que Lopo Pérez e o conde de Trastámara foron os causantes das ditas desfeitas ${ }^{13}$. Unha vez rematada a guerra, parte das propiedades da mitra, en especial a fortaleza de Melide, quedaron en abandono, xa que o arcebispo Fonseca non se ocupou do seu estado nin de mandalas reparar. A causa fundamental é que se achaba inmerso nos problemas sucesorios da corte castelá, motivo que aproveitou o conde de Monterrei, Sancho de Ulloa, para facerse co dominio e posesión das Terras de Abeancos, e no ano 1490, tras o falecemento da súa nai, Inés de Castro, ocupa a fortaleza de Melide e comeza a súa reparación, coa excepción das súas murallas, polo que obvia o mandado real dos Reis Católicos de seren entregadas as posesións da mitra en Melide ao corrixidor real. Isto provoca preitos e litixios entre o conde de Monterrei e o arcebispo Alonso de Fonseca II, pero no ano 1498, mediante un acordo entre ambos, este último cédelle materiais da fortaleza para proceder á ampliación do mosteiro de Sancti 240 Spiritus así como do hospital para a atención de pobres e peregrinos rexido polos mesmos franciscanos, situados extra muros da vila ${ }^{\mathbf{1 4}}$. Finalmente, as Leis de Toro, asinadas por Fernando o Católico en 1505, impiden a reconstrución da fortaleza de Melide e das súas murallas, o que provoca a súa total desaparición.

Cómpre indicar que quedan vestixios hoxe visibles da fortaleza de Melide nas diferentes obras que levou a cabo Sancho de Ulloa coas pedras do derrocado castelo e cedidas polo arcebispo. Ese labor viuse reflectido nas obras emprendidas na igrexa do convento de Sancti Spiritus, que foi reedificada na súa totalidade nos derradeiros anos do século xv. Froito desa reforma só se conserva na actualidade a capela maior (posto que a antiga nave e a torre foron substituídas polas actuais, produto das reformas efectuadas na segunda metade do século XVIII). De aí pode desprenderse, e todo o parece indicar, que as dúas pequenas portas laterais que aínda se conservan, a do lado da epístola, que conduce á capela do Santo Cristo (única parte da edificación orixinal do convento do ano 1372), e a do lado do evanxeo, que conducía ao claustro, poden ser poternas do derrocado castelo ${ }^{15}$. Tamén é moi probable, aínda que non se atoparon documentos que o confirmen, que a porta do hospital de peregrinos puidese pertencer ao castelo, xa que a tipoloxía é máis propia dunha edificación do século xIV que do XVI. Do que si queda constancia é das marcas de canteiro que podemos ver nos

13. O escudeiro Lope Pérez de Mesía liderou unha facción ao mando do duque de Arjona que foi a responsable do derrocamento da fortaleza de Melide (Preito T-F, folios 257v e 245r).

14. Preito T-F, folios $245 v$ e 275 r-v. En Hermida Rodríguez 1985a.

15. Como suxire o maxistrado e correspondente da Real Academia Galega Manuel Taboada Roca. 
perpiaños da ábsida da cabeceira, algunhas delas mutiladas, o que nos indica a súa reutilización nesa posterior construción.

De todos os xeitos, non coñecemos as dimensións que podería ter o castelo nin as hectáreas que ocupaba a súa fortificación. Nas descricións que fan as testemuñas do preito só describen as edificacións, pero non así a superficie total sobre a que se asentaba. A localización onde podía situarse atópase nunha superficie amesetada duns $8300 \mathrm{~m}^{2}$. Comparándoo con estruturas análogas e contemporáneas como o castelo de Pambre $\left(3000 \mathrm{~m}^{2}\right)$ ou a Rocha Forte $\left(4000 \mathrm{~m}^{2}\right)$, a fortaleza de Melide podería ocupar un espazo de similares ou de meirandes medidas se incluímos as construcións adxectivas e as casas da servidume que estarían asociadas á torre e das que falan no preito. Na actualidade pode distinguirse nidiamente no outeiro do Castelo un cumio amesetado e con proliferación de bancadas cara ao norte e oeste, que denotan os traballos de habilitación e acondicionamento.

No século XVII xa non quedaban restos visibles da fortaleza nin das súas murallas, como menciona o cardeal Hoyo no seu Libro de Visitas: «junto a la villa de Mellid a un lado de ella como se va a Santiago a mano derecha en un cerrillo avía una fortaleza. Está ya en el suelo, y solo hay los vestigios della». Parece ser que tan só en algo máis dunha centuria dende o seu derrocamento xa non quedaba practicamente resto ningún da fortaleza ${ }^{\mathbf{1 6}}$.

Un dos temas máis interesantes con respecto a esta edificación é a subministración e captación de auga, xa que ata o de agora non se atopou ningún indicio de pozo ou alxibe onde puidesen abastecerse. Certo é que nas proximidades se atopan a fonte de Sabián e a fonte do Castro, dous dos recursos hídricos e de abastecemento da vila de Melide ata o ano 1889, cando se instalan as fontes públicas no centro da vila decimonónica. Pero estas fontes quedaban fóra do perímetro amurallado, polo que é posible que existise no interior do recinto algún tipo de almacenamento nalgunha edificación construída para tal efecto, sen que se coñeza ata o momento se podería existir algún tipo de alxibe ou pozo practicado no terreo natural ${ }^{17}$. Sábese que existía unha mina de auga na base do promontorio cara á fonte de Sabián (cegada nos anos 80) e tamén que nunha casa da rúa que linda co outeiro do Castelo polo lado leste se localiza un burato ou conduto, o que a lenda e as crenzas populares deron en identificar como pasadizos da fortaleza, quizais tamén de entrada a unha mina.

16. Taboada Roca 1933.

17. No castelo de Pambre o alxibe estaba situado nunha das torres esquinais da muralla. 
A vila de Melide entre fins do século XV e principios do século XVI

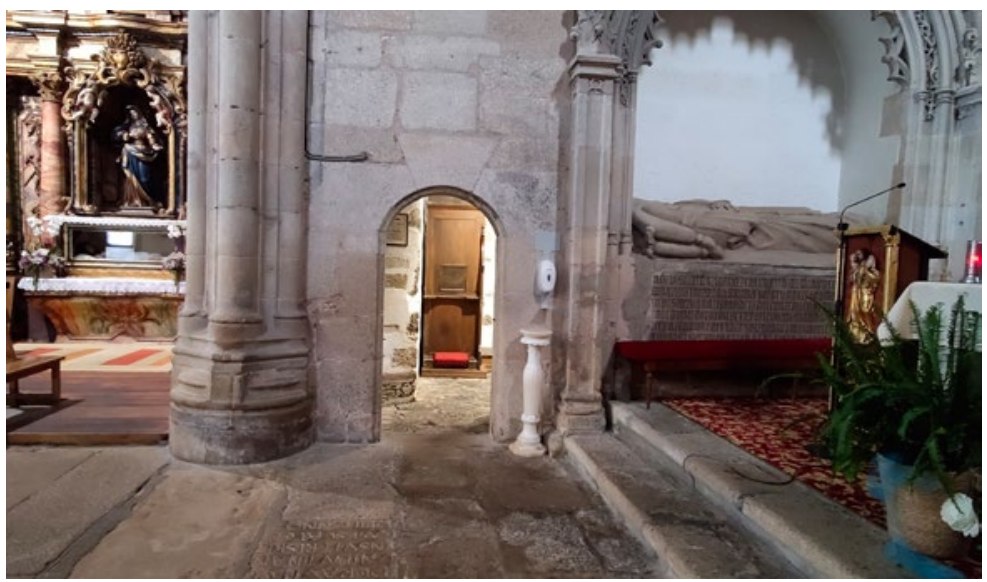

Portas laterais na capela maior da igrexa de Sancti Spiritus. Pode tratarse de poternas do castelo.

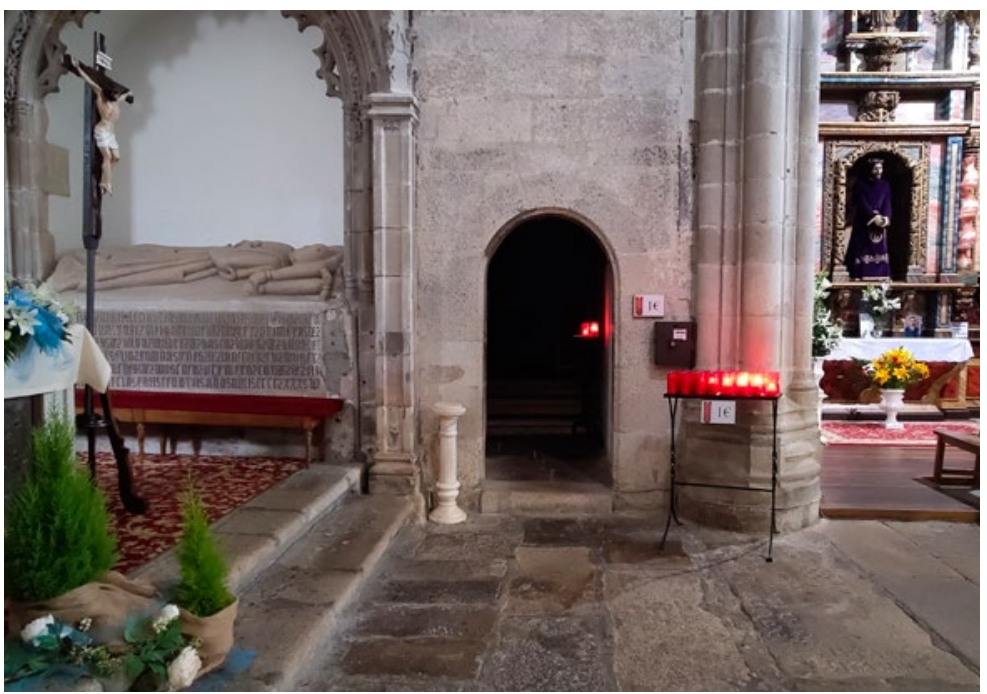


Cristina Vázquez Neira e Xurxo Broz Rodríguez
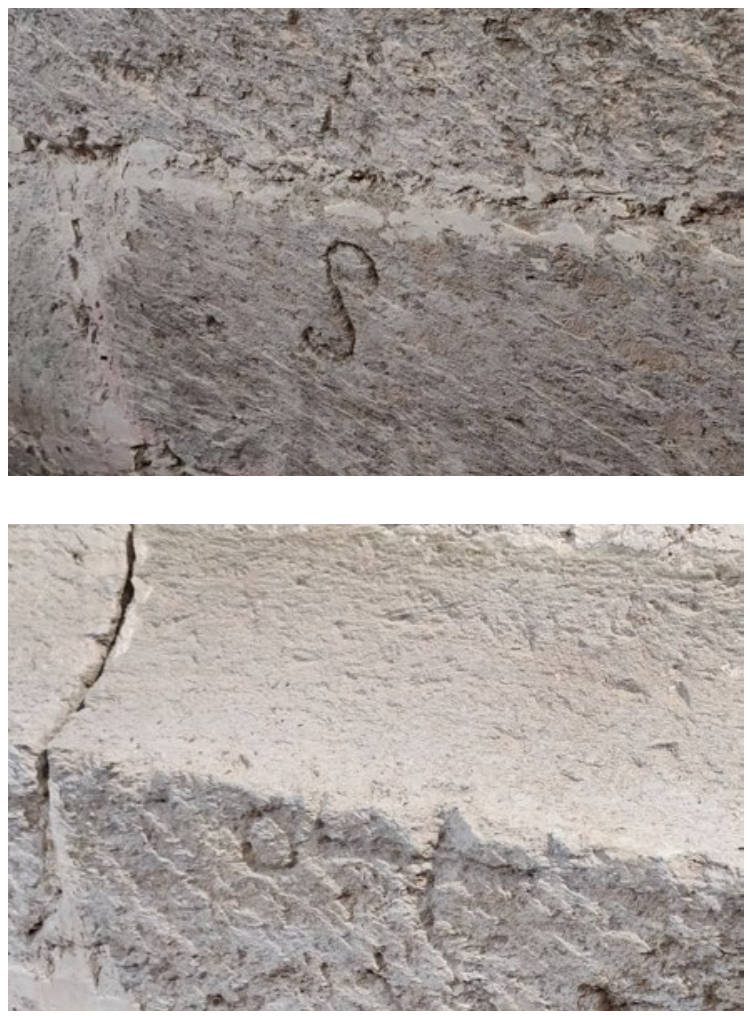

Fig. 4 e 5:

Marcas de canteiro na ábsida da igrexa de Sancti Spiritus. Pódese ver unha delas mutilada para adaptala á nova edificación.

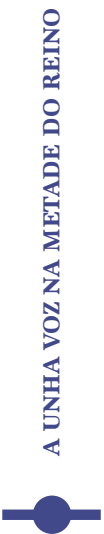

243
Fig. 6:

Oco aberto na rocha, na parte posterior dunha vivenda na rúa Castelo, que a tradición identifica con pasadizos do castelo. Foi tapiada por motivos de seguridade.

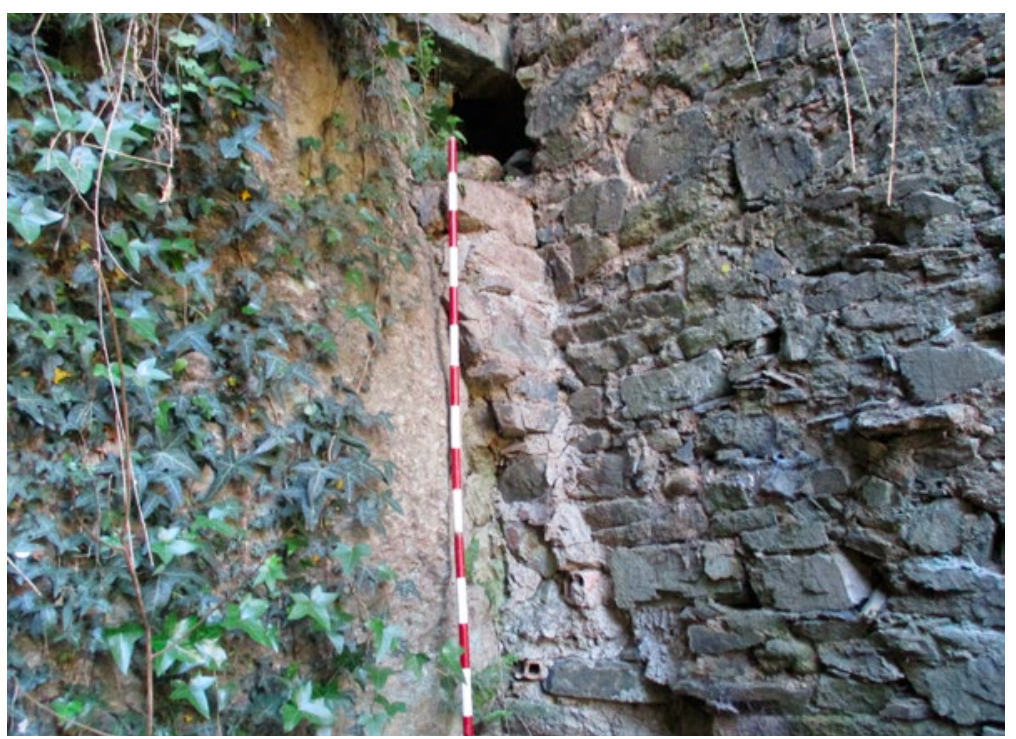




\section{- Orixes do Burgo}

Descoñécense as orixes da vila de Melide. A través de varios documentos podemos extraer datos que nos acheguen á súa posible fundación ou repoboamento en época medieval. Sabemos, a través dunha carta asinada en Lugo polo rei Afonso IX o 4 de abril de 1213, que lle foi concedida á enfermaría do mosteiro de Sobrado dos Monxes a décima parte das rendas cobradas na vila de Melide, que de novo fora repoboada polo mesmo monarca, «tal e como se cobraban no Burgo Vello» ${ }^{\mathbf{1 8}}$. Esta doazón sitúanos en dous escenarios: por unha parte, fálanos dun Burgo Vello, a posible orixe da vila de Melide; por outra, das rendas recadadas na vila novamente repoboada aos pés do castro, onde posteriormente se asentaría a fortaleza da mitra. Podemos deducir, daquela, que o espazo que ocupa a vila nos séculos XV e XVI foi produto dunha repoboación a inicios do século XIII, aínda que hai constancia documental de que xa existían casas aos pés do castro polo lado oriental no século XII, na zona onde posteriormente se asentaría esa nova poboación. Así, existen dúas escrituras de venda, datadas en 1189 e 1204, dun soar na rúa San Pedro «sub illa domo ques est fratum hospitalis» ${ }^{19}$ ou de varios inmobles na mesma rúa adquiridos polo mosteiro de Sobrado entre os anos 1164 e $1206^{20}$.

Existe un documento conservado na catedral de Santiago e datado o 17 de agosto de $1017^{21}$ no cal se pode ler como a raíña dona Elvira, viúva de Bermudo II, doaba «in Oppido Aviancos» dúas igrexas en Milierata (posible Melide), xunto a outras posesións ${ }^{22}$. Deste documento podemos desprender a existencia dunha aldea ou lugar de Melide situado nas Terras de Abeancos, pero probablemente faga referencia ao Burgo Vello asentado nos Tagarros, nas proximidades da igrexa de Santa María, xa que a documentación refire un Burgo Vello e un Burgo Novo, asentado este aos pés do castro.

O Burgo Vello estaría vinculado á igrexa parroquial de Santa María de Melide, polo que a súa propia toponimia xa nos está indicando a primitiva localización do núcleo altomedieval. A actual igrexa data do ano 1185 e no seu adro podemos atopar dous enterramentos antropomoformos escavados na rocha,

18. Taboada Roca 1933.

19. Hermida Rodríguez 1984

20. Hermida Rodríguez 1984 (notas de Carmen Pallares Méndez 1979).

21. Tombo A, fol. 36 .

22. Hermida Rodríguez 1981. 
posiblemente dun momento anterior. A situación da igrexa parroquial de Santa María, que leva o nome de Melide, estaría relacionada co primitivo núcleo do Burgo Vello moi próximo á zona dos Tagarros, do que nos fala unicamente un documento do século XVII e do cal se pode concretar a existencia exacta deste poboamento orixinal ou primitivo. Ese único testemuño procede dunha escritura do ano 1628 a favor de Pedro de Segade na que se di que «aforan o prado do Burgo Vello que estaba a carón do río que sal da Fonte do Castro xunto o camiño que ven á vila polos Tagarros» ${ }^{23}$. Desta información podemos conxecturar a posible situación do primitivo Burgo medieval de Melide, xa que na toponimia actual aínda queda constancia desas localizacións: por unha banda, a zona dos Tagarros sitúase na aba sur do monte do castro e constitúe unha zona de valgada pouco protexida que actualmente se atopa separada deste pola estrada nacional; por outra banda, na escritura menciónase a existencia dunha fonte de auga, a fonte do Castro, que ata o século XIX seguiu servindo á actual vila de Melide.

Moi próximo á Igrexa, a escasos $180 \mathrm{~m}$ ao sur, atópase unha elevación denominada A Madorra, cuxo topónimo nos remite enganosamente á Prehistoria. Trátase dun pequeno outeiro de preto de $4000 \mathrm{~m}^{2}$ que supera amplamente as dimensións dunha mámoa. Sobre el especulouse coa posibilidade de se tratar dunha lomba ou asentamento dunha pequena torre, relacionada con funcións de vixilancia e control sobre o Camiño de Santiago con anterioridade á constitución do castelo da mitra. Pero esta hipótese aínda non foi confirmada xa que non foi obxecto de ningún tipo de intervención arqueolóxica.

Dese Burgo Vello apenas quedan máis datos que nos poidan aproximar á súa posible fundación, orixe ou tipo de poboamento. Non ocorre o mesmo co Burgo Novo, que deu orixe ao Melide actual e que foi o que se desenvolveu ao longo dos séculos centrais e finais da Idade Media e inicios da Moderna. Do Burgo Novo, ademais da carta de outorgamento de Afonso IX ao mosteiro de Sobrado, na que cita o cobro das rendas do Burgo repoboado, existen outros documentos que xa nos falan dun asentamento urbano e en desenvolvemento, como a concesión destas terras á Igrexa de Santiago a inicios do século XIII, ou o outorgamento de tenencia que Rodrigo de Padrón lle confire a Fernán Fernández de Aveancos no ano 1316 e no que fai referencia directa á vila de Melide coa intención de cercala cun muro. Este dato tamén nos sitúa fisicamente na nova localización do Burgo Novo, pois, aínda que na actualidade nada se con-

23. Libro Becerro do Convento de Sancti Spiritus, asignado por frei Andrés López. 
serva da cerca nin das portas polas que se accedía, si existe precisa información que nos describe como se configura ${ }^{24}$. De todos os xeitos, non se coñecen datos precisos de cando se puido efectuar o traslado dun burgo ao outro, aínda que se conservan diferentes documentos en que se le que entre os anos 1164 e 1206 existían casas no lugar que ocupará ese poboamento ${ }^{25}$, sen que se coñezan os motivos que levaron ao traslado definitivo, confirmado pola doazón á enfermaría de Sobrado no ano 1213 do rei Afonso IX.

O que si se sabe é que na nova fundación ou repoboamento do Burgo Novo de Melide tiveron fundamental importancia os novos grupos de mercadores e artesáns que se asentaron nunha localización mellor situada, que favorecía as novas transaccións comerciais a través do paso do Camiño Francés.

Desta nova localización e da súa constitución como vila consérvanse os foros asinados no século xIV, baixo o reinado de Afonso XI e sendo arcebispo 246 de Santiago Berenguel de Landoira, e por tanto señor xurisdicional da terra de Abeancos ${ }^{26}$. A maioría das normas asinadas responde fundamentalmente a dereitos e deberes outorgados polo dereito de costume anterior ou dereito consuetudinario, sen ser normas legalmente xurídicas. Pero resulta que as anotacións no documento que recolle estas disposicións dos foros de Melide foron compiladas en dúas datas diferentes, cunha revisión entre os anos $1351 \mathrm{e}$ 1362 durante o arcebispado de Gómez Manrique, polo que non queda moi clara a redacción e sinatura deles. Do que si nos deixa constancia, no entanto, é da existencia dese novo Burgo e da súa condición de vila. Polo tanto, xa temos configurado o espazo que ocupará a partir dese momento a vila de Melide.

24. Tanto no Preito Tavera-Fonseca como en documentos de compravenda ou escrituras dos séculos Xv, XVI e XVII descríbense a cerca da vila, así como o lugar onde se atopaban as portas desta.

25. Pallares Méndez 1979.

26. Consérvase un documento no Tombo A da Catedral de Santiago, folios $72 \mathrm{v}$ e 73 , con algunhas notas en data posterior que recolle esta documentación. 


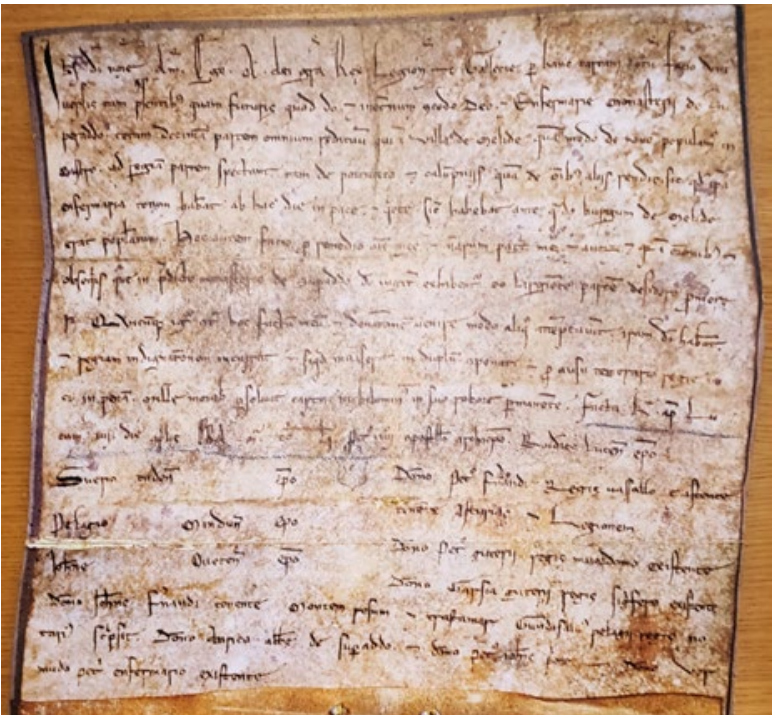

Fig. 7:

Doazón do rei Afonso IX á enfermaría de Sobrado das rendas da vila de Melide. Reprodución cedida polo Arquivo Histórico Nacional e exposta no Museo da Terra de Melide.

Fig. 8:

Plano catastral onde se reflicten as extensións do Burgo Novo de Melide, dos nabais do convento e hospital, así como a localización do castelo e do lugar dos Tagarros. Extraído de mapas.xunta.gal-Centro de Descargas-Información Xeográfica de Galicia.

Fig. 9:

Vista da Madorra de Santa María.
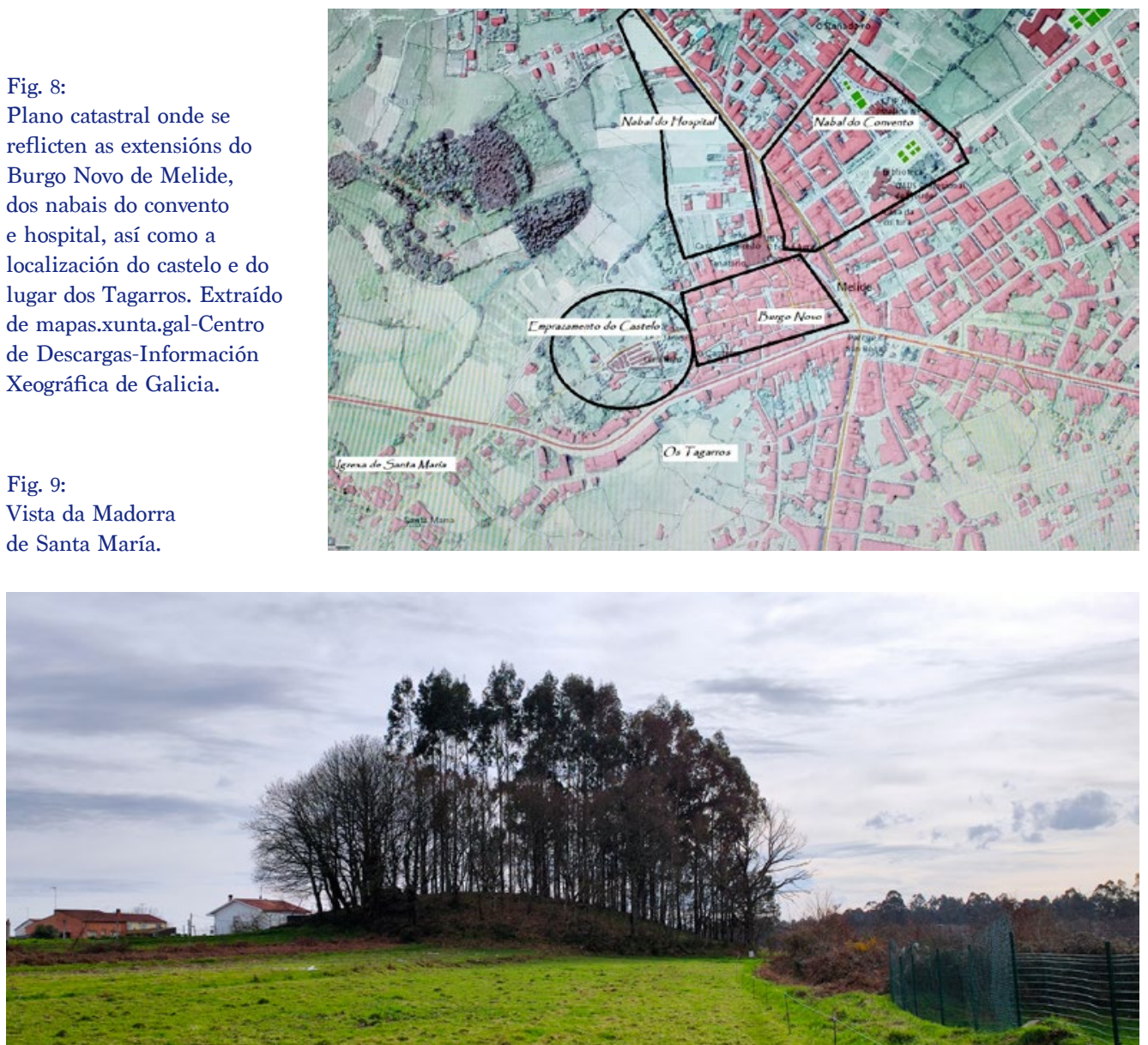


\section{- O Novo Burgo de Melide. Dende as orixes} ata os comezos da Idade Moderna

Resulta especialmente difícil comprender a configuración urbanística do Melide de comezos da Idade Moderna sen retrotraernos aos tres séculos anteriores, posto que nese período o burgo é escenario de intensos episodios que determinarán en gran medida o plano urbanístico vilego. Un plano que, por outra parte, semella non mudar demasiado no tempo ata ben entrado o século XVII, cando se acometen actuacións na praza do Convento ${ }^{27}$ e nas súas rúas adxacentes. Mais non son estas reflexo dun fenómeno expansivo exponencial da trama urbana, posto que non se fai manifesta ata o século XIX, cando se producen os episodios que realmente contribúen a unha expansión urbanística que permite superar os límites constrinxidos do Melide dos tempos medievais e modernos e que 248 teñen que ver con tres aspectos fundamentais:

- Desmantelamento progresivo da antiga cerca medieval, por tratarse dun elemento innecesario e acoutador do desenvolvemento e crecemento urbanístico.

- Desartellamento e atomización das propiedades muradas de labradío (nabais) para aprovisionamento e abastecemento do convento e hospital de Sancti Spiritus da Orde Terceira regular franciscana, acontecida tras a exclaustración da comunidade mendicante por mor da desamortización de Mendizábal, o que permite a construción de estradas e a urbanización serodia das ditas propiedades.

- E, por último, a grande expansión da trama urbana favorecida polo trazado das estradas nacionais Lugo-Santiago e Betanzos-Lalín (deixando esta última en detrimento ao antigo Camiño Real da Coruña a Ourense); sendo ambas as infraestruturas viarias materializadas durante o reinado da raíña Isabel II.

Así, con todo, resulta máis ou menos posible aventurar que o Melide do primeiro cuarto do século XIV, cando pasa alí a noite o monarca Carlos I, e que pouco despois lles serve de punto de reunión aos nobres e prelados do reino de Galicia, non había diferir moito do artellado nos séculos XIII e XIV, agás que o castelo xa fora derrocado na Segunda Revolta Irmandiña, canda a barreira que o fortificaba, que probablemente non desaparecería por completo se non se acadase unha conciliación última entre o arcebispo Alonso II de Fonseca e o conde de Monterrei, Sancho de Ulloa, para poder facer uso das

27. Trátase dun espazo extra muros da vila de Melide durante os séculos baixomedievais. 
pedras da fortaleza inutilizada co fin de reedificar o convento e o hospital de peregrinos de Sancti Spiritus ${ }^{28}$.

Así pois, o núcleo poboacional de Melide a comezos do século XVI contaría cunha superficie reducida, probablemente vinculada á área cercada no século XIV, cando se lle concede ao arcebispo Berenguel de Landoira o privilexio da castelaxe por mester do rei Afonso XI, «[plor facer bien a merced al dicho arzobispo mandovos que tomedes la castellage del día de Santa María de agosto primera que viene fasta seis annos complidos. Porque vos mando vista mi carta que tomedes la dicha castellage para cercar la dicha villa» ${ }^{29}$, cunha pequena área de edificación fóra desta, comprendida entre a vila murada e as fundacións franciscanas de Sancti Spiritus ${ }^{\mathbf{3 0}}$, e tamén con dúas extensas superficies cercadas propiedade do convento (os nabais) que superaban con moito a extensión do Burgo Novo.

No tocante á cerca erguida a partir do 1320 coa concesión da castelaxe, o máis probable é que a súa perda fose gradual, en función das necesidades de expansión urbanística, posto que o que se extrae do Tavera-Fonseca é que o que se derroca é a cerca do Castelo propiamente dita e non a do Burgo Novo, que tería unha función máis de índole fiscal e de protección de saqueos e roubos que defensiva propiamente dita, como se deduce das fontes bibliográficas.

O máis curioso é que esa configuración urbanística non parece terse visto modificada, e para iso de xeito moi puntual, ata o século XIX, cando se reduce o espazo da praza principal do burgo, a do Azougue, actualmente asimilada á da Constitución ${ }^{31}$, ou cando no 1866 o Concello promove a apertura da rúa Nova e prolonga a rúa de Ovedo, que probablemente ata daquela desembocaría na propia praza.

28. Fundado o primeiro no ano 1372 e reedificado no ano 1498, e establecido o segundo no ano 1375 e ampliado e mellorado no 1502 .

29. Hermida Rodríguez 1985a.

30. Actual praza do Convento, un espazo que se reurbaniza no ano 1671 coa fundación da Obra Pía promovida polo arcebispo Mateo Segade Bugueiro.

31. Constitución de Cádiz de 1812, «A Pepa». 


\section{- Aproximación ao modelo urbanístico do Burgo Novo}

Aínda que na actualidade a meirande parte das edificacións existentes no casco vello de Melide (Burgo Novo) foron edificadas dende o século XviII en diante, con predominio das erguidas nos séculos XIX e XX, o certo é que aínda se manteñen en pé edificacións propias da arquitectura popular galega, con aparello de cachote e con cantaría en xambas, linteis, soleiras e antepeitos de ventás que poden datar de comezos da Idade Moderna e que se caracterizan pola sinxeleza estrutural e polas súas modestas dimensións. Mais o que pouco semella que mudase é o trazado urbanístico, que claramente reflicte o pasado medieval da vila, polo que resulta doado comprender como era a trama urbana e as dimensións do burgo, que, aínda que perde por completo a súa cerca de peche, semella acoutado pola probable traza desta.

250 O novo burgo artéllase na banda do nacente do outeiro do Castelo, cunha orientación no eixe LNL-OSO. Conta cunhas dimensións modestas situadas ao redor de 2,75 hectáreas, unha superficie significativamente menor que as dos nabais do hospital e do convento, estimada esta última en 6,40 hectáreas, o que indica a preponderancia do convento de Sancti Spiritus respecto á propia vila.

O trazado é esencialmente lineal, vertebrado por unha longa rúa axial, correspondente ás rúas de San Pedro e Principal (anteriormente identificada como Rúa Maior/Calle Mayor ou como rúa Grande), que conta cun desenvolvemento de $250 \mathrm{~m}$ de lonxitude e coa que se entrecruzan pequenas rúas, canellas e corrupias, entendendo como tales angostos espazos existentes entre edificación. Trátase dunha solución arquitectónica alternativa ás compartimentacións medianeiras, que serven de devasas de propagación de incendios, ademais de valeren para abrir xanelas para dar luz aos sobrados e mesmo tamén para verter augas residuais ${ }^{32}$. Este tipo de recurso é herdeiro dos ambitus adoptados no urbanismo de época romana e que perdura en tempos medievais, coa xeneralización do seu uso nos poboamentos urbanos. Estes espazos angostos son coñecidos en Cataluña como andronas e no Casco Vello de Bilbao ou no de Durango como cárcavas. Por cuestión de salubridade o Concello determina o seu tapiado no ano 1851.

Á antiga Rúa Maior, a media altura pola banda setentrional, sucederíaa un amplo espazo de desafogo e desconxestionamento do urbanismo constrinxido e estreito que caracteriza esas rúas adxacentes á Principal, que se traduce na antiga praza do Azougue (ou de mercado), coñecida con posterioridade como

32. En Melide non se fan obras de saneamento ata o século XIX. 
praza do Pan e a partir de comezos do XIX como da Constitución. Ese espazo que hoxe se coñece popularmente como praza das Coles resulta significativamente reducido pola banda do solpor, polo que as súas dimensións se ven minguadas. Esa praza, de capital importancia, contaba cunha picota ou rolo xurisdicional e sempre actuou de espazo comercial. No Preito Tavera-Fonseca xa se fai mención á praza do Azougue en referencias ás portas da fortaleza que se abrían pola banda do nacente e que actuaban de comunicación coa vila: «la entrada y portada que benía de la villa de Mellid dicho castillo e fortaleza e otra portada que salia del castillo para el azogue». A esta praza principal do Burgo Novo sucédea pola banda occidental a praza do Pozo Pequeno, denominada dese xeito porque nela había un pozo público con peitoril constituído por catro pedras de cantaría que probablemente se corresponda cun espazo xa determinado en tempos medievais e o cal lindaría coa cerca da vila que discorrería pola banda do mediodía da rúa de Santo Antón.

Tamén son frecuentes nese Melide vello os recantos ou pequenas praciñas sen saída que se producen en determinadas rúas e se traducen en ensanchamentos puntuais destas para permitir a apertura de fachadas a ámbitos lixeiramente menos comprimidos ou afogados. Unha mostra dese modelo de superficies de desconxestionamento é habitual nas rúas travesas perpendiculares á Principal pola banda setentrional ou tamén no propio eixe vertebrador existente en paralelo á Principal, pola banda do mediodía, que, partindo da rúa do Castelo, chega ata a praza da Herba e é coñecido como rúa das Ichoas (antigamente Congostra da Barbacá) e que comunica unha sucesión de praciñas das que parten calellas que serven de espazos de paso e servidume. Ese eixe paralelo á rúa Principal, e cun desenvolvemento tan cambiante e intricado, posiblemente se artellaba arredor do lenzo meridional da antiga cerca, sen que se poida precisar con exactitude, por falta de vestixios e referencias, por onde discorrería o peche da vila por esa banda, aínda que nas fontes bibliográficas se recolle que quedarían extra muros «todos los inmuebles y predios de su arcén del mediodía» ${ }^{33}$. 


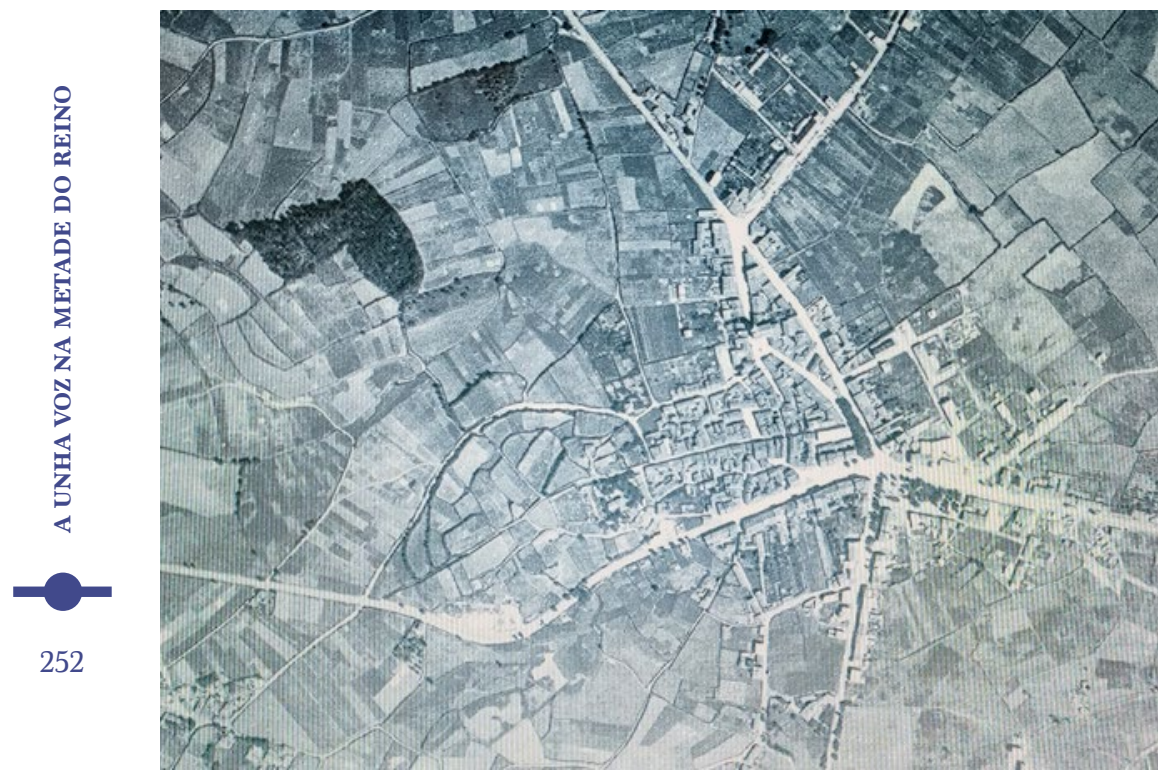

Fig. 10:

Voo americano de 1957 onde se pode ver perfectamente parte dos muros que aínda se mantiñan, dos nabais do convento e do hospital.

Extraído de mapas. xunta.gal-Centro de Descargas-Información Xeográfica de Galicia.

Fig. 11:

Corrupia tapiada entre dúas vivendas da rúa Principal.

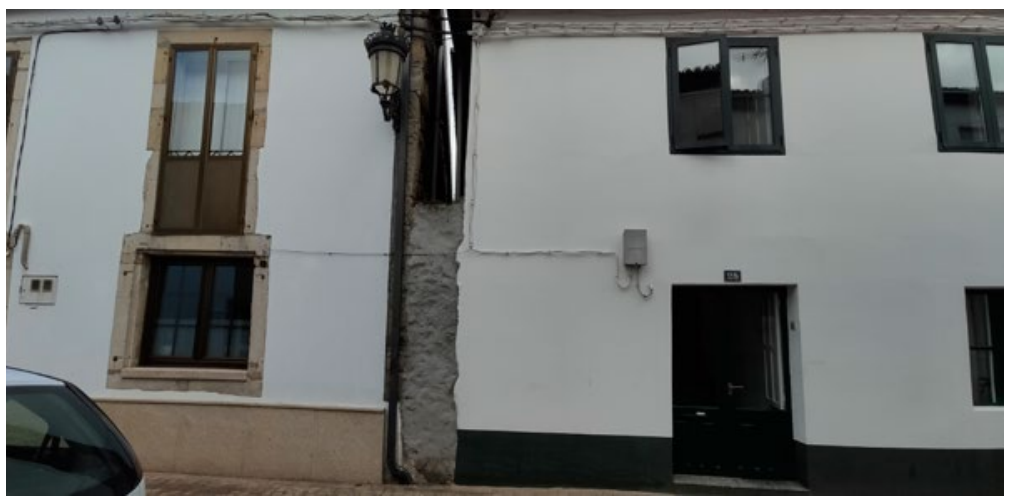

Fig. 12:

Recanto e canella de comunicación entre a rúa Principal e as Cavadas.

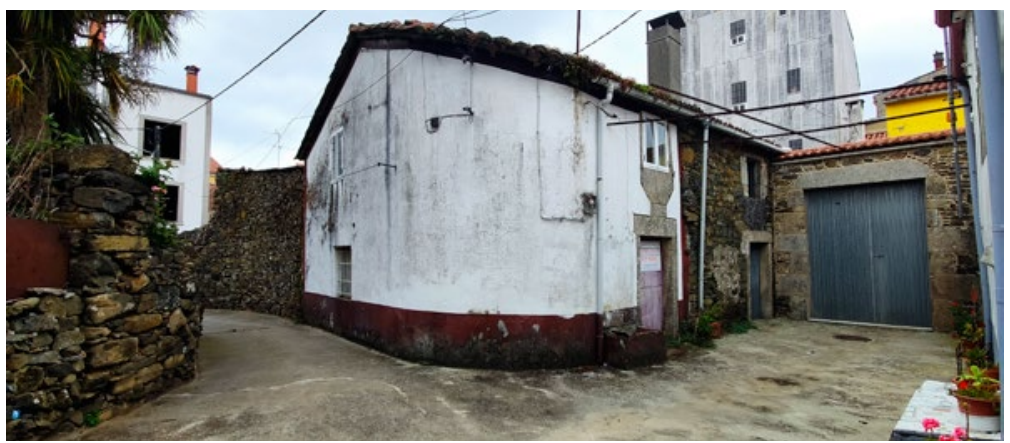




\section{- A cerca de Melide}

Respecto á cerca do burgo, erguida no ano 1320 por concesión do dereito ou beneficio da castelaxe, na actualidade non se conservan vestixios nin tampouco se atopou plano que debuxe o seu trazado. Pero por sorte hai referencias ás súas portas e tamén existe unha foto da actual rúa do Convento datada no ano 1915, na que se pode contemplar unha cerca elevada que serviría de peche da propiedade da Casa de Pedrosa ou Pazo da Vila ${ }^{34}$. Aínda que a cerca pechaba a propiedade fidalga, resulta factible que se trate da única imaxe existente da antiga cerca do burgo, con base en dúas evidencias:

- Que a propiedade da dita casa (identificada como a Mansión Magna), posesión do mosteiro de Sobrado no século XIV, aínda que fundada con anterioridade e reedificada na Idade Moderna, chegaba ata a rúa do Convento. Rúa pola que ademais de discorrer o tramo urbano do antigo Camiño Real que comunicaba A Coruña con Ourense tamén actuaría de límite da cerca da vila pola banda oriental, na que se abría a porta de San Pedro, da que se documenta a súa existencia no ano 1424.

- Mais tamén resulta moi rechamante a técnica construtiva con aparello rexo, de cachote concertado, que se asemella en boa media ao cerco murado da propiedade do mosteiro de Sobrado, e principalmente o seu notable alzado, que ben puidese servir para remedio de «muchos males e dannos e robos de cavalleros e escuderos e de otros poderosos porque la dicha villa no es cercada», como se refire no documento de concesión real da mercé da castelaxe ao arcebispo Berenguel de Landoira.

No Libro Becerro do Convento de Sancti Spiritus ${ }^{35}$ recóllese como se fala dunha propiedade sita na rúa de Ovedo fundada sobre a cerca «y da las demarcaciones en la cerca de la villa y aun oy se hecha de ver la cerca sobre que ella está fundada; fue esta venta año de 1542». Así, vemos que a cerca do burgo se mantén en pé, polo menos de xeito parcial, en séculos sucesivos ao século XV, cando se derroca o castelo e o seu amurallamento. Nese senso, resulta especialmente relevante sinalar, como importante dato clarificador, como aparecen citadas algunhas das portas da cerca, a de Abeancos e a das Cavadas, nas páxinas do Tombo de Sobrado, sempre en datas do século XVI (1509 e 1587), co que resulta evidente que perduraron á contenda irmandiña.

34. Pazo urbano situado na rúa de San Pedro e demolido na década de 1940.

35. Folio $28 \mathrm{v}$. 
Tamén se reflicte no libro Terra de Melide ${ }^{36}$ como en sesión plenaria do 12 de xaneiro de 1841 o Concello determina sacar a poxa a portada principal que quedaba ao lado do castelo.

No Tavera-Fonseca recóllese como o castelo estaba cercado por unha cerca e barbacá e sinálase a existencia de dúas portas de comunicación do castelo coa vila. Probablemente unha delas sexa a que o Concello poxa no ano 1841, polo que podemos considerar que, se aínda se mantiña en pé unha das portas do amurallamento do castelo, mellor sorte correrían os lenzos e portas máis adiadas respecto á fortificación.

En todo caso, aínda son moitas as interrogantes que presenta o trazado da cerca e a súa perdurabilidade ao longo dos séculos, pero por sorte hai varias fontes documentais que nos determinan como esta se erguía na marxe meridional da rúa de Santo Antón, a continuación da porta de Ovedo ${ }^{37}$. Tamén no Tombo de Sobrado se constata como pola rúa de Santo Antón discorría o itinerario urbano do Camiño Francés, entre a cerca e unhas cortiñas ou terras de labor que se sitúan extra muros (entre a vila e o nabal do hospital).

Pola banda oriental, no nacente, só se documenta a porta de San Pedro, probablemente á altura da igrexa parroquial de San Pedro de Melide, erixida polo gremio de comerciantes da vila a fins do século XIII e demolida no ano 1949.

Pola banda do mediodía, documéntase a porta de Abeancos e recentemente atopouse unha referencia a unha porta á altura da rúa da Moa. Por último, e polo flanco do poñente, existirían as dúas entradas que se refiren no Tavera-Fonseca e que corresponderían a portas de comunicación entre o castelo e o burgo, que son as xa mencionadas «entrada y portada que benia de la villa de Mellid para el dicho castillo e fortaleza e otra portada que salía del castillo para el azogue».

Con todo, podemos entender que Melide contaba cunha cerca con cinco portas cara ao exterior e outras dúas de comunicación entre o castelo e o núcleo habitacional ${ }^{38}$.

36. Taboada Roca 1933: 320 .

37. Treito norte da cerca na que tamén se abría a porta das Cavadas, fronte ao camiño do mesmo nome, e onde se conserva aínda un longo treito da cerca do nabal do hospital, que conta cunha lonxitude duns 400 metros lineais, segmentados en dous lenzos dispostos en escuadro.

38. Broz Rei 2016. 


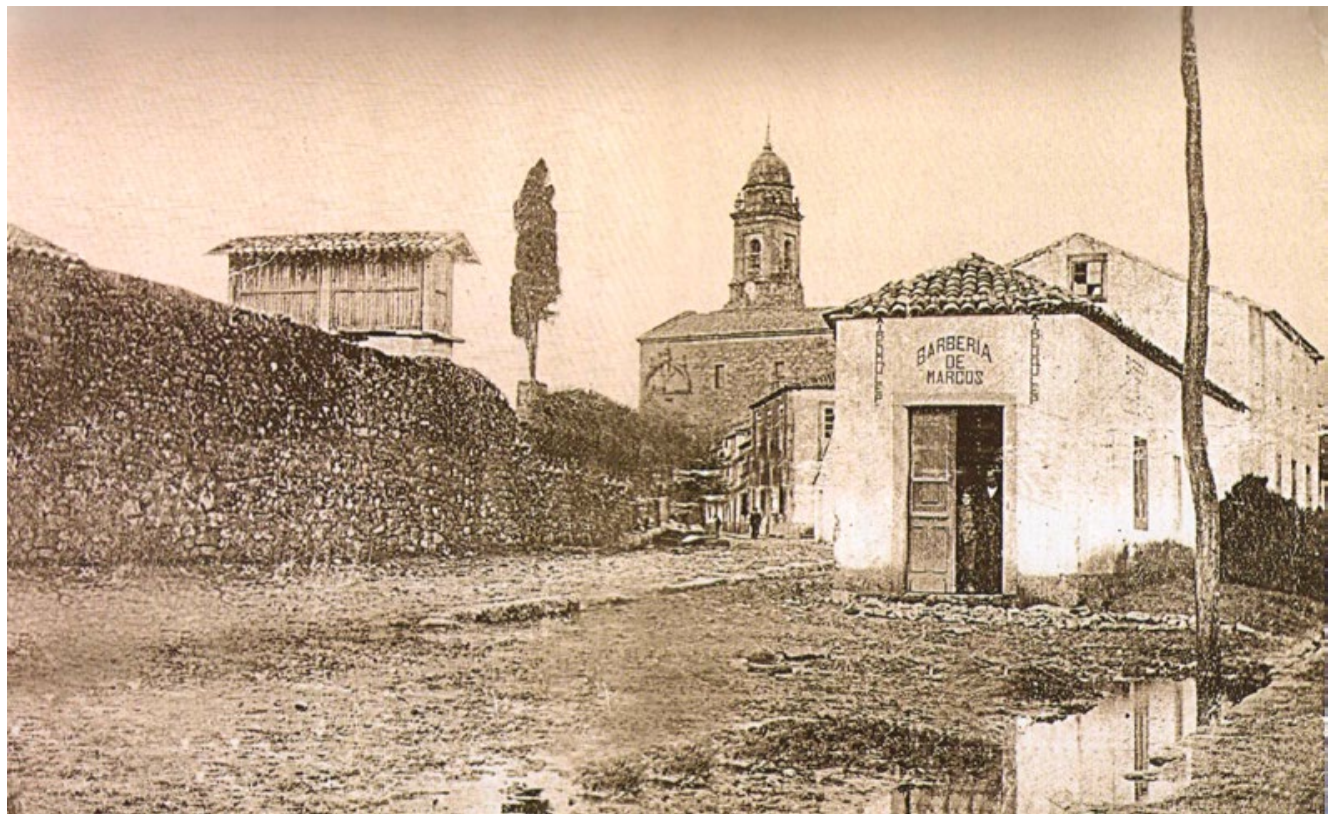

Fig. 13:

Imaxe tomada no ano 1915 na que se pode apreciar o muro de peche da propiedade da Casa de Pedrosa, o cal podería tratarse da antiga cerca do Melide medieval, xa que seguía o mesmo trazado. 


\section{- Sociedade e oficios}

O novo Burgo de Melide, artellado en relación co Camiño de Santiago, ou así se desprende das fontes documentais e bibliográficas, apenas semella diferir doutros burgos de formación medieval espallados pola xeografía galega no que ten que ver co campo das actividades produtivas e ocupacións da súa poboación. Aínda que nun principio se apunta a que a principal actividade dos habitantes do Burgo Vello se relacionaría co agro e por extensión coas principais derivacións dos sectores primarios, dedúcese, por extractos dos foros de Melide outorgados durante o arcebispado de Berenguel de Landoira ${ }^{39}$, como a principal ocupación no Novo Burgo ten que ver co artesanado e coas actividades mercantís. Mais iso probablemente non quere dicir que se abandone a actividade agraria, posto que esta é inherente a un asentamento de mercado como o que nos ocupa.

Así pois, son varios os oficios documentados que nos axudan a comprender polo miúdo o modelo produtivo e a estruturación social. Un dos documentados era o dos cambistas ou cambiadores de moeda, o que denota que Melide na época baixomedieval era un relevante lugar de fluxo comercial. Nese eido, unha das casas documentadas no Tombo de Sobrado, que se localizaba na rúa Principal, era a Casa das Balanças, onde se regularían pesos e medidas. Nesa liña apunta Hermida Rodríguez ${ }^{\mathbf{4 0}}$ :

andando los años los cambiadores ponían pública y autorizadamente el dinero, con sus intereses, de un lugar a otro, y finalmente se dedicaban a préstamos usuarios: las Partidas establecieron para ellos una rígida reglamentación [...]. A pesar de la autorización legal, la población de origen agrícola no estimaba el oficio acorde con la ética cristiana.

Dese xeito, o mesmo autor suxire que sería unha práctica desenvolta por xudeoconversos, probabilidade que non se descarta debido a que xa no Tombo de Sobrado se recollen nomes propios de xudeus como Jacob ou tamén se fai mención a un tal Urias Pérez Alfayate (que reflicte unha condición de xastre), que no ano 1390 adquire coa súa dona unhas casas na "carnecería de Mellide». Así pois, e como é lóxico a partir da expulsión de 1492, moitos deses xudeus acaban marchando a reinos próximos como o de Navarra ou o de Portugal e

39. Entre os anos 1318 e 1330.

40. Hermida Rodríguez 1985a. 
os que quedan acaban por se converteren, de aí que na documentación manexada a partir desa data xa non atopemos reminiscencias xudías nin mencións a comunidades xa definidas como sefardís a partir dos decretos de expulsión. Nesa liña, algúns autores como Broz Rei ou Ónega López defenden a presenza de comunidades xudías no Melide baixomedieval con base na documentación manexada. Mais, e deixando a un lado a presenza ou non de xudeus no burgo, o certo é que no Tombo de Sobrado aparecen testemuñas de venda de casas que desempeñan diferentes actividades e entre eles figura diversos mercadores ou un tal Pedro Pérez cambeador.

Outro dos oficios documentados era o de forneiro, de feito hai mencións tanto ao «Orno grande, ó forno vello», como a unha «Rúa dos Fornos», como se constata nun foro datado no ano 1469 onde se menciona: «por cima topa na Rúa pública como van con su celeyro y parten un vaxo en outra Rúa dos Fornos». Tamén se destaca o oficio de carniceiro en repetidas referencias, tanto na mención a diversos carniceiros como á recorrente Casa da Carnecería, fundada polo arcebispo Berenguel de Landoira durante o seu ministerio episcopal.

Pero por riba de todos destaca o oficio de zapateiro, moi mencionado en documentos de venda e aforamentos datados nos séculos XVI e sucesivos. Así pois, establécese unha confraría gremial, xa nomeada a comezos do século XV, que, baixo a advocación de santa Catarina de Alexandría (e con capela no lado da epístola da igrexa conventual de Sancti Spiritus), contaba cuns estatutos reguladores das actividades do gremio, que agrupaba tanto a zapateiros como a curtidores de peles. A confraría gremial contaba cunha casa en propiedade chamada da Atahona, Ataona ou Hataona, e tamén cuns píos de curtir e muínos para moer a cacha de carballo e obter taninos apropiados para o proceso de curtido. Esa actividade de moído probablemente se desenvolvería na contorna da praza da Moa e da rúa do mesmo nome.

A actividade da confraría e as actas desta aparecen recollidas no Libro de la Confradía, que ofrece un exhaustivo e fondamente detallado percorrido polas constitucións e rendas desta no intervalo comprendido entre os anos 1686 e 1832. Esta confraría tan referenciada e fondamente regulamentada chega ao seu ocaso no ano 1819. Xa que logo, é doadamente comprensible como este oficio foi o máis relevante no Melide de finais da Idade Media e tamén na Idade Moderna.

Outros oficios documentados no Burgo de Melide son os de notario, juiz, alcayde, escudero, clérigo, mercader, tonelero, ferrador, carpintero e sastre. Tamén na Idade Moderna se documenta no Libro Becerro de Sancti Spiritus a existencia 
de casas con función de mantenza, como a mencionada no ano 1665: "Alonso de Romay de quien fue la Cassa y Messon junto al Castelo». Ou tamén no 1678 se dá conta da existencia do Mesón Grande, situado entre a igrexa de San Pedro e a praza Principal. Máis xa no ano 1384 se fai mención a unha casa na que «ora mora Ferna Lopes taverneiro».

En relación coa actividade de mercado no actual casco vello de Melide, na rúa Principal e noutras rúas secundarias, aínda se conservan algúns exemplos de edificacións tradicionais de vivenda en cuxa planta inferior se abren ventás á rúa con peitorís ou antepeitos con cornixas de pedra lixeiramente voadas, ao igual que na aldea medieval do Leboreiro. A este tipo de mostradores domésticos sempre se lles asociou unha finalidade de venda de produtos, o que reflicte claramente como Melide sempre tivo tradición de transaccións comerciais.

\section{- Conclusión}

Xa para rematar, pódese deducir que o Melide de comezos do s. XVI, cando tivo lugar a asemblea, en pouco podería diferir do Melide dos séculos baixomedievais.

Estamos nun escenario bastante convulso, poderíase dicir de certa ausencia de poder, posto que non é ata ao ano 1530 cando se lle restitúe o señorío e xurisdición sobre o burgo á mitra compostelá, mediante executoria do Consello de Castela. Precisamente co gallo do pasamento do conde de Monterrei, Sancho de Ulloa, no ano 1505, non coñecemos quen asume a xurisdición, posto que este deixa a propiedade dos seus bens á súa filla Francisca de Ulloa y Zúñiga $^{41}$ (casada con Diego de Acebedo Fonseca, fillo de Alonso II de Fonseca en primeiras nupcias e con Fernando de Andrade en segundas), mais non lle podería ceder o dominio da tenencia da vila, posto que realmente non a posuía legalmente.

A principal diferenza co Melide previo á Revolta Irmandiña é a desaparición do castelo e do seu sistema defensivo, polo que deles apenas quedarían vestixios en alzado, pero consideramos que aínda se manterían en pé diferentes tramos da cerca da vila. Era esta unha vila de reducidas dimensións pero ben artellada e provista, como se extrae da documentación, con algunhas edificacións relevantes intra muros, como o pazo da Vila ou Mansión Magna, a Casa do Sal, a

41. Falece dona Teresa en 1526 ou 1527 (non está clara a data), polo tanto, anteriormente a serlle devolta a posesión da vila de Melide á mitra compostelá. 

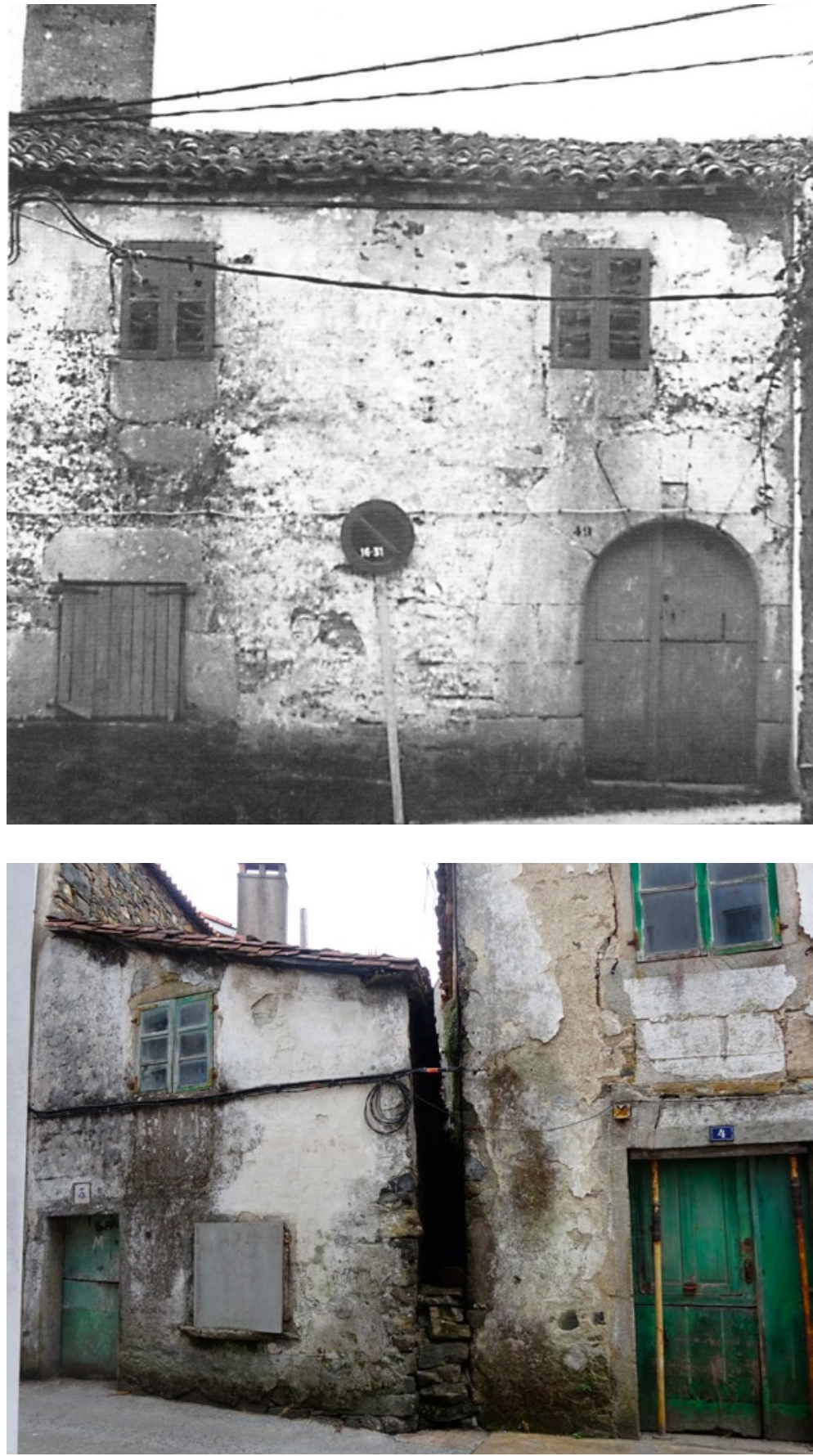

Fig. 14:

Imaxe da década de 1980 da Casa de Romay ou mesón, hoxe desaparecida, na que se pode apreciar a súa estrutura medieval con arco de medio punto na porta de entrada.

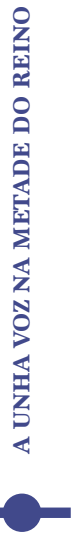

259
Fig. 15:

Nesta imaxe podemos observar dúas vivendas antigas separadas por unha corrupia. Na casa situada á esquerda vemos así mesmo unha ventá con mostrador. 
das Balanzas, a da Carnizaría, o hospital de San Pedro e a igrexa parroquial da mesma advocación.

Extra muros destácase, por riba de todo, o convento de Sancti Spiritus, o principal convento da Orde Terceira regular franciscana de Galicia (con toda probabilidade o lugar onde se celebrou a asemblea de 1520), co seu hospital de peregrinos, reedificado no ano 1502, no que se presume que empregaron pedras do derrocado castelo e en cuxo baixo estaba instalada a panadaría do convento. Tamén sobresaen as dúas grandes propiedades muradas de labor, os nabais que superaban amplamente a superficie do novo burgo, o que fai comprensible entender a preponderancia do convento respecto a unha vila onde moitas das casas son da súa propiedade ou do mosteiro de Sobrado. Tamén extra muros se erguía a ermida de San Sebastián (desaparecida no século XVI, momento en que puido chegar a coexistir coa capela de San Roque, que 260 acababa de ser fundada) e xa máis afastada estaba a de San Lázaro, vinculada a unha malata ou hospital de leprosos. Extra muros igualmente se sitúan as fontes públicas de Sabián e a do Castro (nos Tagarros), aínda que intra muros habería un número indeterminado de pozos. 


\section{- Referencias bibliográficas}

Álvarez García, Xulio (1990): «Melide: a formación urbana en cinco imaxes», Boletín do Centro de Estudos Melidenses, Museo da Terra de Melide, 5, 22-32.

Broz ReI, Xosé Manuel (1991a): «Libro Becerro do Convento de Sancti Spiritus de Melide. Arquivo Diocesano de Santiago», Boletín do Centro de Estudos Melidenses, Museo da Terra de Melide, 6, 87-153.

Broz Rei, Xosé Manuel (1991b): «Libro do Hospital de Sancti Spiritus, Arquivo Parroquial de Melide», Boletín do Centro de Estudos Melidenses, Museo da Terra de Melide, 6, 203-227.

Broz ReI, Xosé Manuel (2000): «Tumbo de Sobrado», Boletín do Centro de Estudos Melidenses, Museo da Terra de Melide, 13, 122-139.

Broz Rei, Xosé Manuel (2001): «Apuntes da Historia de Melide», Boletín do Centro de Estudos Melidenses, Museo da Terra de Melide, 14, 57-96.

Broz Rei, Xosé Manuel (2003): «O Melide vello», Boletín do Centro de Estudos Melidenses, Museo da Terra de Melide, 16, 7-74.

Broz Rei, Xosé Manuel (2004): Santispiritus de Melide. Edición do autor.

Broz Rei, Xosé Manuel (2016): A vila de Melide. Edición do autor.

Broz Rei, Xosé Manuel / Ma Dolores Primo BarJa (1992): «Apéndice documental: Libro Becerro do Convento de Sancti Spiritus de Melide. Arquivo Diocesano de Santiago», Boletín do Centro de Estudos Melidenses, Museo da Terra de Melide, 7, 167-222.

Broz Rei, Xosé Manuel / M ${ }^{a}$ Dolores Primo BarJa (1993): «Apéndice documental: Libro Becerro do Convento de Sancti Spiritus de Melide. Arquivo Diocesano de Santiago», Boletín do Centro de Estudos Melidenses, Museo da Terra de Melide, 8, 359-368. 
Broz Rei, Xosé Manuel / Ma Dolores Primo Barja (1995): «Libro Becerro do Convento de Sancti Spiritus de Melide (continuación da transcripción)», Boletín do Centro de Estudos Melidenses, Museo da Terra de Melide, 9, 228-253.

Broz Rei, Xosé Manuel / Ma Dolores Primo Barja (1997): «Libro Becerro do Convento de Sancti Spiritus de Melide (continuación da transcripción)», Boletín do Centro de Estudos Melidenses, Museo da Terra de Melide, 10, 234-256.

Broz Rei, Xosé Manuel / Mª Dolores Primo Barja (1998): «Libro Becerro do Convento Franciscano de Sancti Spiritus de Melide (continuación)», Boletín do Centro de Estudos Melidenses, Museo da Terra de Melide, 11, 248-271.

Broz Rei, Xosé Manuel / Ma Dolores Primo Barja (1999): «Libro Becerro do Convento Franciscano de Sancti Spiritus de Melide (continuación)», Boletín do Centro de Estudos Melidenses, Museo da Terra de Melide, 12, 237-248.

Broz Rei, Xosé Manuel / Ma Dolores Primo Barja (2000): "Libro Becerro do Convento Franciscano de Sancti Spiritus de Melide (Continuación)», Boletín do Centro de Estudos Melidenses, Museo da Terra de Melide, 13, 140-151.

Broz Rei, Xosé Manuel / Ma Dolores Primo BarJa (2001): «Libro Becerro do Convento Franciscano de Sancti Spiritus de Melide (Continuación- final)», Boletín do Centro de Estudos Melidenses, Museo da Terra de Melide, 14, 200-232.

González López, Emilio (1980): La Galicia de los Austrias, A Coruña, Fundación Pedro Barrié de la Maza.

Hermida Rodríguez, Antonio (1981): "Mellid hace mil años», Libro de Festas do San Roque, Melide.

Hermida Rodríguez, Antonio (1982): «Los Ulloa y Mellid s. XV», Boletín do Centro de Estudos Melidenses, Museo Terra de Melide, 1, 21-24.

Hermida Rodríguez, Antonio (1984): «Primeros cien años del Mellid de la Nueva Puebla (1212-1316)», Libro de Festas do San Roque, Melide. 
Hermida Rodríguez, Antonio (1985a): «Amurallamiento del Burgo de Mellid», Libro de Festas do San Roque, Melide.

Hermida Rodríguez, Antonio (1985b): «Acotaciones a los fueros de Mellid», Boletín do Centro de Estudos Melidenses, Museo Terra de Melide, 3, 88-94.

Mejuto Sesto, Manuel (2006): «Mil anos de pertenencia a unha igrexa», Boletín do Centro de Estudos Melidenses, Museo da Terra de Melide, 19, 111-133.

Mejuto Sesto, Manuel (2007): «Mil años de pertenencia a una iglesia: las relaciones de melide con la iglesia mindoniense. Primera parte», Boletín do Centro de Estudos Melidenses, Museo da Terra de Melide, 20, 83-128.

Pallares Méndez, Ma del Carmen (1979): El monasterio de Sobrado: un ejemplo de 263 protagonismo monástico en la Galicia medieval, A Coruña, Deputación Provincial.

RodríGuez GonzÁLEz, Ángel (1984): Las fortalezas de la Mitra compostelana y los Irmandiños: pleito Tabera-Fonseca, A Coruña, Fundación Pedro Barrié de la Maza.

Taboada Roca, Antonio (1933): «Notas históricas», en Terra de Melide, Santiago de Compostela, Seminario de Estudos Galegos, 137-250.

Taboada Roca, Manuel (1983): «O antergo Castelo de Melide», Boletín do Centro de Estudos Melidenses, Museo Terra de Melide, 2, 4-6.

TABoada Roca, Manuel (1990): «As “corrupias" da nosa vila», Boletín do Centro de Estudos Melidenses, Museo da Terra de Melide, 5, 5-11. 